\title{
Vegetatively reproductive red clovers (Trifolium pratense L.): An overview
}

\author{
M.G. HYSLOP, P.D. KEMP and J. HODGSON \\ Institute of Natural Resources, Massey University, Palmerston North
}

\begin{abstract}
Although the persistency of red clover (Trifolium pratense L.) can be a problem when grazed in mixed and pure stands, it is still regarded as a valuable source of high quality summer feed in some farming systems. Vegetatively reproductive red clover selections offer promise to solve this persistency problem but their growth, perennation, reproductive ability and productivity have not been investigated in New Zealand farming systems. This paper is an overview of a 4 year research programme involving nine experiments investigating these areas. The vegetatively reproductive red clovers evaluated were Astred, F2419 and Gualdo. There was no difference between Astred and Grasslands Pawera, a crown type red clover, in the total herbage accumulated over the first growing season under 4, 6 and 8 week grazing frequencies and lax and hard grazing intensities. After 3 years of grazing, significantly more Astred parent plants were alive compared to Pawera when rooted plantlets were counted as parent plants after one year. Varying numbers (0-66 plantlets $\left./ \mathrm{m}^{2} / \mathrm{yr}\right)$ of rooted plantlets were produced by Astred in mixed and pure swards. More rooted plantlets were established per parent plant under wet surface soil conditions. Astred produced $57 \%$ of its autumn rooted plantlets on primary stems developed in September, or branches off these stems. Comparisons of the growth and morphology of Astred, F2419 and Gualdo are presented. Red clover selections that are vegetatively reproductive offer benefits to New Zealand farming systems and could solve some of the persistency problems currently experienced with red clover.
\end{abstract}

Keywords: Astred, F2419, Gualdo, rooted plantlet, Trifolium pratense, vegetatively reproductive

\section{Introduction}

Red clover (Trifolium pratense L.) has been widely reported to have poor persistency when grazed in mixed and pure stands, with total loss of plants after 2 to 3 years (Brougham 1959, 1960; Harris et al. 1980;
Cosgrove et al. 1985; Sheath et al. 1989; Frame 1990; Hume et al. 1995). Yet, red clover is a valuable source of high quality summer feed in some farming systems. All red clover cultivars used in New Zealand grow from crowns and predominantly reproduce from seed, though some reproduce vegetatively to a small extent (Hyslop et al. 1996). The crowns are susceptible to treading damage and fungal infection, particularly in winter, resulting in poor persistence (Hay et al. 1989). Pure stands of red clover usually only persist 3 to 4 years.

Red clover selections exist that have prostrate stems that produce clonal plants at nodes which may improve persistency in grazed pastures. Smith et al. (1993) reported the chance discovery of vegetatively reproductive red clover plants by the Department of Agriculture, Tasmania in 1975, in seed accessions gathered from Crato, Portugal. These plants produced strong, prostrate stolons (here termed stems) in late summer, and clonally formed daughter plants (here termed rooted plantlets). These formed from unelongated growth at lateral stem buds, below which nodal roots formed after flowering. Whether all are capable of producing nodal roots is unknown. The rooted plantlets usually appeared within $100 \mathrm{~mm}$ of the parent plant, and as they developed roots, the connection to the parent plant degenerated. The cultivar Astred was developed from this material (Smith et al. 1993).

Astred was more persistent than conventional cultivars when grazed with sheep over a 3 year period in Tasmania, retaining $55 \%$ ground cover after 3 years compared to $5 \%, 2 \%$ and $0 \%$ for Grasslands Turoa, Grasslands Hamua and Redwest, respectively (Smith et al. 1993). In New Zealand, Astred was the most prevalent of the introduced legumes in experiments on easy hill slopes and continued to persist under grazing (Orr et al. 1996).

Because of the relatively recent commercial release of the first two vegetatively reproductive red clovers, cv. Astred in 1992 and cv. Gualdo in 1998, published results and information on these cultivars and the plant type in general are limited. Gualdo was bred out of accessions collected in Italy by J.P. Baresel, Strada di Calledro, Italy. F2419 is an accession from material gathered in Portugal and provided by W. Rumball, AgResearch. Hyslop et al. (1996) concluded that the perennation and productivity of such red clovers 
required further evaluation to determine their potential in New Zealand farming systems, and the vegetative reproduction mechanism needed to be understood clearly before appropriate management strategies could be developed. The objective of this paper is to present an overview of the research programme that followed. Most research was based at Massey University, Palmerston North, and focused on the production, persistence and demography of the vegetatively reproductive red clover selections, Astred, F2419 and Gualdo. Pawera was used as a comparison as it is widely considered the most persistent red clover cultivar under New Zealand conditions.

\section{Materials and methods}

All experiments are fully described in Hyslop (1999). An overview of the objectives, designs and methods of the eight experiments follows.

The persistence of individual parent plants and the annual and seasonal herbage production of Astred were measured in three field experiments to examine the productiveness of Astred under practical farming conditions:

Experiment 1 (Massey University) compared the herbage production and parent plant persistence of pure swards of Astred and Grasslands Pawera when grazed by sheep. There were 12 treatments (two cultivars, Astred, Pawera; two grazing intensities, hard $(5 \mathrm{~cm})$, lax $(10 \mathrm{~cm})$; three grazing frequencies, 4, 6 and 8 weeks) over a 3 year period in a randomised complete block design $\left(48 \times 118 \mathrm{~m}^{2}\right.$ plots $)$. Two hundred parent plants were tagged 1 year after sowing in the Astred and Pawera 6 week hard grazed treatments and these were monitored over time (Figure 1). Experiment 2 was sown (27 September 1996) as a mixed sward at Dannevirke in a completely randomised design with Grasslands Pawera as a comparison cultivar, and grazed by replacement dairy heifers (Hyslop et al. 1998). Parent plant persistence and rooted plantlet production were measured. Experiment 3 was sown as a mixed sward in a completely randomised design at Massey University, No. 1 Dairy. Parent plant persistence, rooted plantlet production and seasonal production of Astred were measured. Experiment 4 was sown at Hawke's Bay in 1996. However, all plants died in the summer of 1998 due to lack of soil moisture and the findings will not be reported here (Hyslop et al. 1998).

Experiments 5 to 9 examined morphological, environmental and grazing management effects on the formation of plantlets and rooted plantlets:

Experiment 5 was a split plot design imposed on pure swards of Astred at Massey University that had previously had one season of hard grazing $(5 \mathrm{~cm}$ residual height) by sheep, with grazing frequencies of 4 and 8 weeks. The treatments were hard and lax grazing (residual heights of 5 and $10 \mathrm{~cm}$ respectively) at 4 and 8 week grazing intervals. The plantlets and rooted plantlets that developed on parent plants over 6 months (JanuaryJune) were counted.

Experiment 6 (Massey campus block) consisted of 60 spaced Astred seedlings in a completely randomised design with no cutting or grazing. Flower buds were removed from 30 plants as they formed and the remaining plants went to full seed set to determine whether flowering affected rooted plantlet formation.

Experiment 7 investigated what effect dry or wet soil surface moisture levels had on rooted plantlet formation over time, in a completely randomised design with 30 parent plants per treatment, under a rainout shelter with irrigation and no grazing at AgResearch, Palmerston North. The soil surface around the parent plants was initially wet or dry, and then after 29 days, water was also applied to the dry treatments (termed dry/wet). All parent plants were regularly watered separately from the surrounding soil watering treatments by the use of waterproof barriers.

Experiment 8 (Massey University) consisted of 15 plants of Astred and 15 of F2419 planted as spaced plants $(3 \mathrm{~m} \times 3 \mathrm{~m})$ in a completely randomised design with no cutting or grazing. Parent plant stem age and number, and rooted plantlet number and position on the parent plant were assessed to identify where rooted plantlets form on parent plants.

Experiment 9 (Massey University) compared morphological characters of two vegetatively reproductive red clovers, Astred and Gualdo, in a completely randomised design with 30 plants of each cultivar. Plants were destructively harvested at 10 months of age.

\section{Results and discussion}

\section{Annual production}

Astred and F2419 can both reproduce vegetatively via rooted plantlets $\left(0-80 / \mathrm{m}^{2}\right)$ in mixed and pure swards under New Zealand farming conditions (Hyslop et al. 1996; Hyslop et al. 1998; Experiments 1, 2, 3 and 5). When Astred was sown in either a mixed or pure sward, annual production was similar to that of Pawera (Experiments 1 and 3) suggesting its production is not unduly compromised by its vegetative reproductive mechanism. Annual production of Astred (13 592 $\mathrm{kgDM} / \mathrm{ha}$ ) was not significantly affected by the grazing treatments in the first year although there was a difference of $3361 \mathrm{kgDM} / \mathrm{ha}$ between the highest producing treatment (Astred, 6 weeks, lax) and the lowest producing treatment (Astred, 8 weeks, lax) in Experiment 1. In a mixed sward at No. 1 Dairy Farm, 
Massey University (Experiment 3) Astred's annual production was $4040 \mathrm{kgDM} / \mathrm{ha}(\mathrm{SEM} \pm 272)$ in 1996/ 1997 and $2300 \mathrm{kgDM} / \mathrm{ha}(\mathrm{SEM} \pm 223)$ in $1997 / 1998$ (Table 1). However, the hard and frequent grazing management of the sward resulted in poor survival of rooted plantlets so the production decline was related to the decline in parent plants of Astred. Astred declined from 30 plants $/ \mathrm{m}^{2}$ in 1996 to 4 plants/ $\mathrm{m}^{2}$ in 1998 , except for an increase in winter/spring 1997 when rooted plantlets that were formed in autumn (14 plantlets $/ \mathrm{m}^{2}$ $\mathrm{SEM} \pm 2.4$ ) were counted as independent parent plants, but these rooted plantlets only slowed the rate of parent plant decline to 4 plants $/ \mathrm{m}^{2}$ in 1998.

\section{Seasonal production}

Because of Astred's Mediterranean origins, it has a comparable growth pattern to Grasslands Colenso and Grasslands Hamua. All Astred grazing treatments in Experiment 1 accumulated significantly more herbage from sowing to the first spring grazing on 20 September 1996 than did Pawera $(\mathrm{P}<0.01)$ (Table 3). Differences ranged from an extra $2540 \mathrm{kgDM} / \mathrm{ha}$ for the Astred, 8 weeks, hard treatment to $1910 \mathrm{kgDM} / \mathrm{ha}$ for the Astred, 6 weeks, hard grazed treatment.

Table 1 Seasonal production of pure Astred and Pawera swards grazed every 6 weeks to $5 \mathrm{~cm}$ post grazing height in the first year from sowing (kgDM/ha), (Experiment 1).

\begin{tabular}{lccc}
\hline Harvest date & Astred & Pawera & SEM \\
\hline 8 March 1996 & 0 & 0 & - \\
20 September 1996 & 4540 & 2620 & 204 \\
3 November 1996 & 1760 & 2990 & 276 \\
9 December 1996 & 1850 & 2270 & 277 \\
20 January 1997 & 3400 & 3440 & 442 \\
24 February 1997 & 1240 & 850 & 357 \\
7 April 1997 & 800 & 1450 & 227 \\
Total & 13590 & 1362 & \\
\hline
\end{tabular}

The high winter growth activity of Astred could be useful in mixed forage swards for calving cows or for adding quality and bulk to the first silage cut of the season (Figure 1). Astred out-produced Pawera in a mixed pasture sward by $1000 \mathrm{kgDM} / \mathrm{ha}(\mathrm{SEM} \pm 296)$ when cut for silage in spring (7 November 1997), after a conservation period of 102 days, at Dannevirke (Experiment 2) (Hyslop et al. 1998). In contrast, Astred only produced $7.7 \%$ of the silage production in Experiment 3 when cut 1.75 years from sowing with a conservation period of 53 days, but parent plant density was only 15 plants $/ \mathrm{m}^{2}$ (Hyslop et al. 1998).

In the first year from sowing (1996) in Experiment 3 , Astred produced $1480 \mathrm{kgDM} / \mathrm{ha}(\mathrm{SEM} \pm 72)$, or $25 \%$ of total sward production in spring (September, October, November) and $2410 \mathrm{kgDM} / \mathrm{ha}(\mathrm{SEM} \pm 165)$, or $55 \%$ of total sward production in summer (December, January, February) (Table 1). Seasonal production of Astred decreased in 1997, as parent plant numbers declined, to $1000 \mathrm{kgDM} / \mathrm{ha}(\mathrm{SEM} \pm 49)$ or $32.3 \%$ of total production.

Table 2 Percentage contribution to seasonal yield by Astred sown in a mixed sward (Experiment 3).

\begin{tabular}{llcc}
\hline & Season & Astred & SEM \\
\hline 1996 & Autumn & 7.4 & 2.0 \\
& Winter & 6.8 & 1.7 \\
& Spring & 25.0 & 1.2 \\
1997 & Summer & 54.7 & 3.8 \\
& Autumn & 12.8 & 4.7 \\
& Winter & 10.2 & 1.8 \\
1998 & Spring & 14.8 & 1.6 \\
& Summer & 32.3 & 1.1 \\
& Autumn & 4.6 & 1.6 \\
\hline
\end{tabular}

\section{Parent plant persistence in pure swards}

Astred and Pawera parent plant persistence were compared in six grazing treatments in Experiment 1. Astred swards had significantly higher $(\mathrm{P}<0.01)$ percentages of parent plants remaining (rooted plantlets counted as parent plants after 1 year of age in Astred swards) in all grazing treatments after two growing seasons compared to Pawera (which can only remain the same or decline because of nil parent plant replacement). By year three, there was a significantly greater percentage of parent plants surviving in the lax than the hard grazing intensity $(\mathrm{P}<0.01)$, and in the 8 week than the 4 week grazing frequency. The greatest rate of parent plant death was over winter and early spring, particularly in the hard and 4 weekly grazed treatments of both cultivars.

At 2.6 years of age, after two seasons of grazing, Astred also had significantly more originally sown parent plants than Pawera $(\mathrm{P}<0.05)$ (see Figure 1). At all earlier dates, the rate of original parent plant decline was the same for both cultivars. More Astred than Pawera parent plants were present at Dannevirke (Experiment 2) after 2 years $(\mathrm{P}<0.01)$. At the last count on 27 May 1998, the parent plant densities of Astred and Pawera, were 36 plants $/ \mathrm{m}^{2}$ and 30 plants $/ \mathrm{m}^{2}$ (SEM \pm 0.87 ), respectively (Hyslop et al. 1998).

Astred parent plant populations tended to have more parent plants $/ \mathrm{m}^{2}$ than Pawera, but these parent plants were significantly smaller in dry mass after two seasons of grazing in comparison to Pawera (Experiment 1). Similarly, Astred (1.6 gDM/root) had lighter individual tap-roots across all treatments compared to Pawera (2.4 $\mathrm{gDM} /$ root, $\mathrm{SEM} \pm 0.197, \mathrm{P}<0.01)$. Significantly $(\mathrm{P}<0.01)$ less tap-root mass $\left(0.60 \mathrm{kgDM} / \mathrm{m}^{2} \mathrm{SEM} \pm\right.$ 0.09 ) remained in hard $(5 \mathrm{~cm}$ grazing residual height) 
and frequently grazed (4 week) treatments for both cultivars 3 years from sowing in Experiment 1 compared to all other treatments (average of $1.26 \mathrm{kgDM} / \mathrm{m}^{2} \mathrm{SEM}$ $\pm 0.09)$.

Figure 1 Percentage of original tagged parent plants remaining in Astred and Pawera pure swards that were grazed every 6 weeks to $5 \mathrm{~cm}$ residual sward height by sheep (Experiment 1).

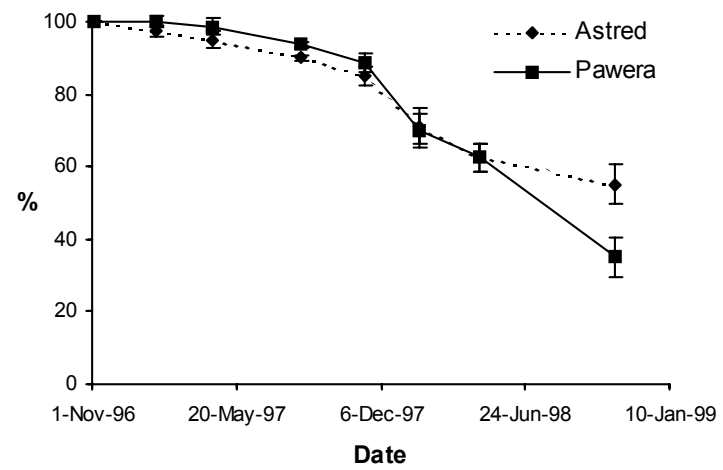

\section{Plantlet formation}

\section{Pure and mixed grazed swards}

Astred and F2419 rooted plantlet production in autumn was affected by the number of spring grown stems on the parent plant that were still present, and by autumn soil moisture levels (Experiments 6 and 8). Rooted plantlet size is also important for survival in grazed swards (Hyslop et al. 1996).

There is large morphological variation in the selections of red clover capable of vegetative reproduction, and some of these selections are able to reproduce vegetatively at lower post-grazing residual heights than Astred (Experiments 8 and 9). In Experiment 8 Astred produced most of its rooted plantlets on primary stems, or branches off these stems, that grew from the parent plant crown in September, whereas F2419 produced rooted plantlets equally on stems originating from July though to September (Table 3). In general, a high percentage of rooted plantlets developed on stems originating in spring, but they also developed to varying extents on stems originating at other times, depending on the red clover selection (Experiment 8). Therefore, because of this seasonal effect, the grazing history of vegetatively reproductive red clover, particularly Astred, will affect plantlet and rooted plantlet formation. Hard grazing of Astred in spring would appear to greatly diminish the sites available for plantlet formation.

When Gualdo and Astred were compared morphologically, Astred produced significantly $(\mathrm{P}<0.01)$ fewer rooted plantlets per parent plant, had longer, wider leaves, thicker stems and was taller at 10 months of age. There were no significant differences in stem length, stems per plant, nodes $/ \mathrm{m}$ of stem, total parent plant dry matter and stem, leaf and tap-root dry matter.

Table 3 The frequency of rooted plantlets per 15 parent plants produced by Astred and F2419, on 6 June 1997, from primary stems and branches off primary stems produced from 1 July 1996 to 1 February 1997 (Experiment 8).

\begin{tabular}{lrr}
\hline $\begin{array}{l}\text { Month of primary } \\
\text { stem growth }\end{array}$ & Astred & F2419 \\
\hline July & 26 & 330 \\
August & 72 & 353 \\
September & 213 & 392 \\
October & 59 & 154 \\
November & 3 & 9 \\
December & 0 & 0 \\
January & 0 & 0 \\
February & 0 & 0 \\
\hline
\end{tabular}

The seasonal production of rooted plantlets was highly variable between and within all experiments. In the pure swards of Experiment 1 on 10 June 1997, there was a significant interaction $(\mathrm{P}<0.05)$ between grazing frequency and grazing intensity for the number of rooted plantlets produced. Astred, 8 weeks, lax grazed produced $46 \%$ (66 plantlets $\left./ \mathrm{m}^{2}\right)$ more rooted plantlets than Astred, 8 weeks, hard grazed (36 plantlets $/ \mathrm{m}^{2}$ ) and 56\% (29 plantlets $/ \mathrm{m}^{2}$ ) more than Astred 6 weeks, hard grazed. Grazing intensities at the 4 week grazing frequency did not affect the number of rooted plantlets produced, with 43 and 42 plantlets $/ \mathrm{m}^{2}(\mathrm{SEM} \pm 5.1)$ for hard and lax treatments, respectively.

In a mixed sward (Experiment 2), rooted plantlet density of Astred (measured on 27 May 1998) after two seasons of grazing was 64 rooted plantlets $/ \mathrm{m}^{2}$ (SEM \pm 1.7 ) from a population of 32 parent plants $/ \mathrm{m}^{2}$. Silage was cut in the second spring of the experiment. In contrast, when parent plants were under high grazing pressure (Experiment 3), only 14 rooted plantlets $/ \mathrm{m}^{2}$ $(\mathrm{SEM} \pm 2.4)$ were counted from a population of 16 $(\mathrm{SEM} \pm 1.4)$ parent plants $/ \mathrm{m}^{2}$.

In Experiment 5, significantly more $(\mathrm{P}<0.001)$ rooted plantlets formed and survived grazing by sheep under lax grazing intensity at both grazing frequencies. Nine and 11 rooted plantlets $/ \mathrm{m}^{2}(\mathrm{SEM} \pm 1.5)$, respectively, were produced and survived grazing in May in the 4 weeks, lax and 8 weeks, lax grazed plots. These represented $31 \%$ of the total rooted plantlets produced between January and June. There was no significant difference in the number of rooted plantlets that survived grazing at the two grazing frequencies from January to June. We suggest that Astred swards 
should be grazed to maintain a post grazing height of $10 \mathrm{~cm}$ over spring and summer to ensure sufficient stems survive for the production of plantlets and ultimately rooted plantlets. When grazing pressure was light, Astred and F2419 rooted plantlets were found up to $900 \mathrm{~mm}$ from their parent plant in one season.

\section{Environmental conditions and parent plant maturity}

Parent plants maturing to full flower did not change the number of rooted plantlets produced relative to parent plants with flowers removed $(\mathrm{P}<0.9)$ (Experiment $6)$. The number of rooted plantlets produced per parent plant varied from 0 to 48 with flowers removed and 0 to 19 with no flowers removed, with a high coefficient of variation of $140 \%$. The frequency distributions of the number of rooted plantlets produced per parent plant under the two treatments were not significantly different $(\mathrm{P}<0.2)$. For example, a similar number of parent plants produced three rooted plantlets in both treatments. No relationship $(\mathrm{P}<0.4)$ was found by simple linear regression $\left(\mathrm{r}^{2}=0.02\right)$ between the number of flowers removed and the number of rooted plantlets produced per parent plant.

More rooted plantlets $(\mathrm{P}<0.001)$ were produced per parent plant in the wet irrigation treatment (5 plantlets/ parent plant, $22.2 \%$ gravimetric surface soil water content) than the dry ( 0.3 plantlets/parent plant, 3.71\% gravimetric surface soil water content) treatment from 25 February to 26 March in Experiment 7. After 26 March, surface irrigation was applied to all treatments. There was no difference in the total number of rooted plantlets produced by either wet/wet or dry/wet treatments by the end of the experiment. Rooted plantlets were formed at a significantly greater rate $(\mathrm{P}<0.05)$ for the first 2 weeks after 26 March in the dry/wet treatment than the wet/wet treatment. The time of onset and the duration of autumn rain (comparable to the irrigation treatments imposed) would appear likely to affect the number and timing of rooted plantlets formed. There appears to be some capacity for plantlets produced during a dry spell to generate roots when the soil moistens.

\section{Conclusions}

With some small changes to current grazing management practices and suitable environmental conditions (moist autumn soil conditions), vegetatively reproductive red clovers appear to be truly perennial forage legumes suitable for use in mixed swards and as forage crops. Like the crown type red clovers currently in use, the persistency of Astred, F2419 and Gualdo will be dependent on the intensity, frequency and timing of grazing, with a post-grazing height of $10 \mathrm{~cm}$ important in spring to ensure that stems which generate plantlets and ultimately rooted plantlets, fully develop. Red clover selections that are vegetatively reproductive offer benefits to New Zealand farming systems. Their superior persistency over crown type red clovers is worthy of further research and development.

\section{ACKNOWLEDGEMENTS}

The authors are grateful to the late T. Lynch and M. Osborne for their technical assistance in the field and to P.R \& J. MacIntyre, E. Ross, AgResearch Palmerston North and Massey University for the use of land. The authors also wish to thank W. Rumball, P. Baresel and Wrightsons Seeds Ltd for the provision of seed, and the David Johnstone Memorial Trust for stipend support for M.G. Hyslop.

\section{REFERENCES}

Brougham, R.W. 1959. The effects of frequency and intensity of grazing on the productivity of a pasture of short rotation ryegrass and red and white clover. New Zealand journal of agricultural research 2: 1232-1248.

Brougham, R.W. 1960. The effects of frequent hard grazings at different times of the year on the productivity and species yields of a grass-clover pasture. New Zealand journal of agricultural research 3: 125-136.

Cosgrove, G.P.; Brougham, R.W. 1985. Grazing management influences on seasonality and performance of ryegrass and red clover in a mixture. Proceedings of the New Zealand Grassland Association 46: 71-76.

Frame, J. 1990. The role of red clover in United Kingdom pastures. Outlook on agriculture 19: 49-55.

Harris, W.; Hoglund, J.H. 1977. Influences of seasonal growth periodicity and $\mathrm{N}$-fixation on competitive combining abilities of grasses and legumes. Proceedings of the XIII International Grasslands Congress: 239-243.

Hay, R.J.M.; Ryan, D.L. 1989. A review of 10 years' research with red clovers under grazing in Southland. Proceedings of the New Zealand Grassland Association 50: 181-187.

Hume, D.E.; Lyons, T.B.; Hay, R.J.M. 1995. Evaluation of "Grasslands Puna" chicory (Cichorium intybus L.) in various grass mixtures under sheep grazing. New Zealand journal of agricultural research 38 : 317-328.

Hyslop, M.G.; Kemp, P.D.; Barker, D.J.; Hodgson, J. 1996. Incidence of nodal rooting and plantlet survival in spreading red clovers. Proceedings of 
the New Zealand Grassland Association 58: 243246.

Hyslop, M.G.; Kemp, P.D.; Hodgson, J. (In press). Preliminary investigations into the persistence of a vegetatively reproductive red clover cv. Astred in mixed swards at Hawke's Bay and Manawatu. Proceedings of the Agronomy Society of New Zealand. Hyslop, M.G. 1999. Evaluation of vegetatively reproductive red clovers (Trifolium pratense) for use in pastoral systems. PhD thesis. Massey University, Palmerston North, New Zealand.

Orr, S.J.; Wedderburn, M.E. 1996. Assessing the persistence of some pasture legumes in hill country.
Proceedings of the New Zealand Grassland Association 58: 259-264.

Sheath, G.W.; Hay R.J.M. 1989. Overview of legume persistence in New Zealand. pp. 26-36. In: Persistence of forage legumes. Eds. Martin, G.C; Matches, A.G; Barns, R.F; Brougham, R.W; Clements, R.J; Sheath, G.W. American Society of Agronomy, Inc., Crop Science Society of America, Inc., Soil Science Society of America, Inc.

Smith, R.S.; Bishop, D.J. 1993. Astred - a stoloniferous red clover. Proceedings of the XVII International Grassland Congress: 421-423. 